\title{
ASPECTOS FILOSÓFICOS DA EDUCAÇÃO NO PERÍODO CLÁSSICO GREGO
}

\author{
Sudelmar Dias Fernandes ${ }^{1}$
}

RESUMO: Esse estudo buscou realizar uma reflexão problematizada de algumas questões do pensamento filosófico do período clássico sobre a educação, discutidas a partir das ideias dos filósofos; Sócrates, Platão e Aristóteles. Contempla a importância de seus pressupostos no processo de criação da própria filosofia, sua condição racional na perspectiva do logos, e da formação do povo grego. O presente trabalho contextualiza a discussão inicialmente através do modelo educativo mítico formulado segundo os contos de Homero. Este texto foi desenvolvido por meio de um estudo teórico descritivo através de revisão bibliográfica do tipo narrativa, possibilitando inferir problemáticas investigativas sobre a temática da educação, discutidas a partir das ideias dos três principais filósofos da era clássica da filosofia.

PALAVRAS-CHAVE: Educação; Filosofia; Formação; Clássico.

ABSTRACT: This study sought to make a problematized reflection of some questions to the philosophical thought of the classic period about the education, discussed from the philosophers' ideas; Socrates, Plato and Aristotle. It contemplates the importance 
of its presuppositions in the process of creation of the own philosophy, its rational condition in the perspective of logos, and the formation of the Greek people. The present work contextualizes the discussion initially through the mythical educational model formulated according to the tales of Homer. This text was developed through a descriptive theoretical study through a bibliographical revision of the narrative type, making it possible to infer investigative problems on the subject of education, discussed from the ideas of the three main philosophers of philosophy's classic era.

KEYWORDS: Education; Philosophy; Formation; Classic. 
O período antigo da filosofia ocidental fica caracterizado de forma decisiva pelas diversas tentativas em produzir explicações sobre a realidade do mundo, a relação do homem consigo mesmo e sua ação na polis. Estas especulações estavam de certa forma associadas às vontades e desejos de deuses e mitos. Tais narrativas eram trazidas principalmente pelos contos e poemas dos dois maiores escritores da época, Homero e Hesíodo (700 a.C.). Por consequente, a partir dos conhecimentos advindos destes contos dar-se-á a construção de um saber mítico, de uma cultura centrada nas histórias divinizadas. Tornando-se, portanto, a mais importante fonte de educação da Grécia antiga.

Nesta perspectiva, tem-se nas figuras de seus dois maiores ídolos, Aquiles, na Ilíada, e Odisseu, na Odisseia (século VII a.C.), heróis e modelos do protótipo civilizatório aristocrático grego. Prontamente, Homero tornou-se a principal referência para a educação de toda a sociedade helênica. Segundo JAEGER (1995), Homero teve a capacidade de expressar através de seus poemas e contos uma visão ética e estética dentro de uma proposta cultural e educacional. Além disso, está concepção homérica foi capaz de sobreviver às próprias condições que a motivaram. Assim, completa Jaeger:

Homero é o representante da cultura grega primitiva. Já apreciamos o seu valor como "fonte" do nosso conhecimento histórico da sociedade grega mais antiga. Mas a sua descrição imortal do mundo cavalheiresco é algo mais do que um reflexo involuntário da realidade na arte. Este mundo de grandes tradições e exigências é a esfera mais elevada da vida, na qual a poesia homérica triunfou e da qual se nutriu. O Pathos do sublime heroico do homem 
lutador é o sopro espiritual da Ilíada. O ethos da cultura e da moral aristocrática encontra na Odisséia o poema da sua vida. A sociedade que produziu aquela forma de vida desapareceu sem deixar qualquer testemunho para o conhecimento histórico, mas a sua representação ideal, incorporada na cultura homérica, converteu-se no fundamento vivo de toda a cultura helênica (JAEGER, 1995, p. 66).

Em resposta ao modelo educativo homérico de perceber a realidade posta no mundo, o período clássico da filosofia direciona suas investigações para novas formas especulativas na tentativa de buscar conhecer as coisas. Volta-se para o homem e suas relações com o mundo. Com isso, a filosofia inaugura outras perspectivas de reflexão sobre a realidade do mundo, contidas nele mesmo.

Nesta continuidade, por volta de VI e V a.C. surgem os primeiros pensadores, que mais tarde passam a ser reconhecidos pela história da filosofia como "présocráticos" (ARANHA, 2003). Inicia-se com eles uma série de questionamentos sobre a legitimidade do conhecimento e da educação assentada tão somente nas informações extraídas dos contos míticos. Os pensadores pré-socráticos iram perceber que as explicações dadas para os fenômenos da experiência humana deveriam ser encontradas na própria natureza das coisas. Ou seja, passam a concentrar suas investigações no próprio universo. De modo que, destas especulações, surgem diversas concepções sobre o princípio que rege o mundo - o arché. Com isso, a interpretação destes fenômenos deveria passar necessariamente pelo exame sistemático da razão humana. 
Já podemos observar a diferença entre pensamento mítico e filosofia nascente: os filósofos divergem entre si e a filosofia se distingue da tradição mítica oferecendo uma pluralidade de explicações possíveis, uma atitude característica do filósofo (ARANHA, 2003, p. 84).

Corroborando a este princípio, já no período clássico da filosofia para os seus três maiores expoentes: Sócrates (469-399 a.C.), Platão (427-347 a.C.) e Aristóteles (384322 a.C.), o primeiro grande exercício do conhecimento humano é o compromisso com a verdade. Para tanto, deve o pensamento preservar a causa e a mesma forma, ou seja, como o conhecimento verdadeiro se apresenta ao homem em seu processo de investigação pelo exercício da prática racional.

Deste modo, a filosofia grega busca a própria superação da mítica educacional, afirmando a condição do homem como centrada em uma essência imutável e eterna, perfeita em si mesma, mas comprometida e vinculada com a ação direta dos fenômenos causais. Todo o esforço da filosofia, além de investigar os objetos do mundo, será também buscar conhecer a natureza humana, sua ontologia, igualmente presente no mundo. É precisamente a partir desta natureza humana que a filosofia busca investigar a direção de sua ação, de sua natureza.

O interesse dos filósofos gira, de preferência, não em torno da natureza, mas em torno do homem e do espírito; da metafísica passa-se a gnosiologia e a moral. Daí ser dado a esse segundo período do pensamento grego também o nome de antropológico, pela importância e o lugar central destinado ao homem e ao espírito 
no sistema do mundo, até então limitado à natureza exterior (PADOVANI, 1974, p. 107).

Em vista disso, a filosofia que nasce na Grécia como possibilidade de explicar racionalmente todos os aspectos da realidade no universo, assim como a realidade das ações humanas presentes no mundo, surge também simultaneamente como uma proposta de educação para o indivíduo. A educação constitui deste modo, uma problemática com a qual o homem se confronta na transmissão do conhecimento mítico para o racional. Neste sentido, os gregos, reconhecidos como os fundadores da educação ocidental, buscavam através do esforço individual na polis uma educação pautada na realidade posta no mundo.

Por outro lado, se pode inferir que o nascimento da filosofia, na Grécia, tem como consequência o desenvolvimento de uma pedagogia, ou seja, o ideal prático problematizado na capacidade de conhecer a realidade como forma de educação do homem durante sua existência. Esta experiência educativa, é assim dominado de paideia: uma formação geral que tem por tarefa construir o homem como homem e como cidadão. Platão, segundo Jaeger, define paideia da seguinte forma: "[...] a essência de toda a verdadeira educação ou paideia é a que dá ao homem o desejo e a ânsia de se tornar um cidadão perfeito e o ensina a mandar e a obedecer, tendo a justiça como fundamento" (JAEGER, 1995, p. 147).

Do conceito inicial dado ao termo "paideia" (paidos criança), que significava simplesmente "criação de meninos", este se alarga e toma um sentido muito mais abrangente, consolida-se como a concretização idealizada de um padrão 
educativo na Grécia antiga, como afirma JAEGER (1995). Mas, como esclarece o autor, o entendimento das atividades educativas da paideia só será estruturado a partir do século $\mathrm{V}$ a.C. e vai se assentar em praticas educativas bastante antigas: "Não se pode utilizar a história da palavra paideia como fio condutor para estudar a origem da educação grega, porque esta palavra só aparece no século V" (JAEGER, 1995, p. 25).

Por consequência, a crescente abrangência nas ações e práticas educativas idealizadas pela concepção da paideia passa a incorporar também a continuidade do processo educativo durante toda a vida do homem grego, estendendose, por conseguinte, para além dos períodos apenas escolares. Por isso, a paideia adquire um significado maior:

[...] cultura entendida no sentido perfectivo que a palavra tem hoje entre nós: o estado de um espírito plenamente desenvolvido, tendo desabrochado todas as suas virtualidades, o do homem tornado verdadeiramente homem (MARROU, 1966, p. 158).

Ademais, entre os filósofos pré-socráticos, os sofistas terão o mérito de reconhecer a importância do sujeito humano, já que, para eles, "o homem é a medida de todas as coisas" (COTRIM, 2010, pg 184), e vão radicalizar este conceito para defender a ideia de que os homens deveriam, tão somente, buscar a realidade daquilo que conseguem perceber.

Etimologicamente, a palavra sofista tem origem grega e quer dizer "sábio" (COTRIM, 2010). Estes mestres andarilhos se deslocavam entre as cidades gregas ensinando aqueles 
que podiam lhes remunerar. Conheciam diversos saberes: matemática, filosofia, dialética, erística, retórica, oratória, entre outros. Contudo, não se prendiam apenas a ensinar, buscavam também questionar o estilo autoritário das leis, dos valores, das crenças e das ideias dominantes. Esta forma de pensar e de agir dos chamados filósofos sofistas será decisiva para desencadear algumas transformações na civilização helênica. Como resultado, isso, levaria a Grécia a repensar o modelo de educação vigente (JAEGER, 1995).

É precisamente nesta conjuntura de especulações que os sofistas estão inseridos, e onde suas atividades educativas atingem o apogeu. É ai que surge também, concomitantemente a todo este processo, a figura do filósofo Sócrates (c. 470-399 a.C.), cujo pensamento se desloca para outras maneiras de investigar as questões especulativas da finalidade prática da realidade proposta pelas sofistas. Discordando, frontalmente das ideias defendidas por estes filósofos, Sócrates volta-se não para o homem empírico do conhecimento vulgar, das experiências vividas e praticadas através das tentativas e erros com interesses egoístas, como defendiam os sofistas. De outra forma, vai compreender o homem a partir de sua essência, da natureza que lhe é peculiar, isto é, das finalidades morais deste homem.

Assim como os sofistas, Sócrates começa criticando o conhecimento empírico, vulgar, comum, entretanto ele vai mais além, não restringindo suas especulações filosóficas a uma crítica pura e simplesmente cética. Mas, transcende o saber sensível, individual e mutável na busca do logos racional, um saber que tenha possibilidades universais, de características imutáveis. 
A sua filosofia assume, portanto, condições e finalidades práticas morais, agora sob uma única condição, deve ser orientada pela razão. Deste modo, Sócrates recoloca a problemática da educação (paideia) humana, agora sob novas e revolucionárias perspectivas, centrada na virtude (areté). Propõe uma reforma intelectual e moral propugnando outras bases no educar dos cidadãos gregos, na expectativa de que as ações exercidas lhe dessem as condições necessárias para um olhar reflexivo das práticas em suas próprias vidas.

A Sócrates interessam o homem e suas ações, exatamente aquelas tidas como virtuosas, numa época em que ser virtuoso é quase sinônimo de ser cidadão e tudo se justifica em nome da virtude - até mesmo as injustiças. Ele o que é a sabedoria, a beleza, a coragem, a justiça porque procura, a partir desses diversos aspectos da virtude, chegar à questão das questões: o que é a virtude?

Conhecê-la torna-se, assim, o principal objetivo do verdadeiro conhecimento - só prática o mal quem ignora o que seja a virtude, e quem tem o verdadeiro conhecimento só pode agir bem. Desse modo, conhecimento e virtude tornam-se sinônimos. Com Sócrates as questões morais deixam de ser tratadas como convenções baseadas nos costumes, as quais se modificam conforme as circunstâncias e os interesses, para se tornarem problemas que exigem do pensamento um elucidação racional (COLEÇÃO OS PENSADORES, HISTÓRIA DA FILOSOFIA, 2004, p. 44-45).

Sócrates (471/470-399 a.C.), portanto, se apresenta para o logos de forma inovadora, tanto na especulação filosófica 
quanto para a educação, de tal forma que seu pensamento fornece condições para se fazer inferências pertinentes entre filosofia e educação forjada na mesma finalidade, qual seja: a reflexão racional e prática da vida. Deste modo, Sócrates é considerado não apenas um dos principais modelos de filósofo, também o é na qualidade de um dos grandes educadores da humanidade.

Por conseguinte, reconhecer a possibilidade de uma educação socrática advém principalmente do seu método peculiar de investigação. MONDOLFO (1971) partilha o método socrático como um diálogo crítico (dialética) que se desenvolve em dois momentos: a refutação ou ironia e a maiêutica.

As duas etapas do método, a refutação e a maiêutica, podem ser compreendidas a partir do seguinte processo: a primeira etapa, denominada de refutação ou ironia, caracteriza o momento em que Sócrates procura mostrar a seus interlocutores suas incertezas, suas contradições, a sua insuficiência ao defender posições sobre algo que acreditava ser o conhecimento verdadeiro. É nesta etapa que surge a possibilidade de emergir a verdade. É o momento que possibilita o surgimento da verdade pela supressão do erro, confirmada pela seguinte passagem:

Ele forçava a definir o assunto em torno do qual versava a pesquisa; depois aprofundava-se de vários modos na definição: explicitava as falhas, as contradições às quais levava; convidava em seguida a tentar uma nova definição e, com o mesmo procedimento, confutava-a, e assim por diante, até o momento em que o interlocutor reconhecia-se ignorante (REALE, 1993, p. 310). 
Em seguida, logo após a etapa da refutação, Sócrates apresenta a seus interlocutores uma série de novas questões. Através de perguntas metodicamente elaboradas com a intenção de fazer emergir a luz o verdadeiro logos, do qual, pelo diálogo, seu interlocutor estará apto a conhecer, por já possuir o saber interior, necessitando apenas de alguém que o ajude a encontrálo mediante um processo análogo à arte da parteira, ilustrado nesta citação:

Dissemos que, para Sócrates, a alma só pode alcançar a verdade "se dela está grávida"; ele, de fato, como vimos, professava-se ignorante e, portanto, negava decididamente ser capaz de comunicar aos outros um saber, ou, pelo menos, um saber constituído de determinados conteúdos. Mas, como a mulher que está grávida no corpo tem necessidade do obstetra para dar à luz, assim o discípulo que tem a alma grávida da verdade tem necessidade de uma espécie de obstetra espiritual que ajude esta verdade a vir à luz, e esta é, justamente, a maiêutica socrática (REALE, 1993, p. 312).

Está é, portanto, a base filosófica e educativa de Sócrates. Ao utilizar seu método, que de forma apropriada refuta o conhecimento demonstrado. Por consequente, a presunção do saber, desloca este mesmo conhecimento presente no sujeito para aquilo que pretende saber em essência, não em aparência. Somente assim se poderia estar seguro de oferecer ao indivíduo uma educação que o faça reconhecer a beleza e a bondade, tanto à bondade e beleza em si mesmo quanto na polis.

Para HADOT (1999), a questão central do método socrático é a tomada de consciência por parte do sujeito de suas contradições e incertezas em relação a um suposto saber. 
Ainda segundo o autor, agindo deste modo o indivíduo se distância em parte de si mesmo para se identificar, agora, com Sócrates, em um movimento dialógico dialético. Neste instante há a retomada da consciência de si, pondo-se a si mesmo no cerne do problema. Consequentemente, a verdadeira problemática educativa socrática não está em se buscar o conhecimento verdadeiro, mas, a natureza do saber racional de si, e como este saber deve promover o cuidado do homem.

Platão (427-347 a.C.), o segundo filósofo do período clássico, foi discípulo de Sócrates e se torna um dos maiores filósofos de todos os tempos, mudando radicalmente o cenário do pensamento ocidental, introduzindo novas concepções na história da filosofia. Platão irá versar sobre praticamente todos os grandes temas da filosofia e suas investigações e discussões se tornaram referência inesgotável e presentes até hoje para as reflexões filosóficas.

[...] a força dessa síntese é tal que, em pleno século $\mathrm{XX}$, o filósofo inglês Alfred N. Whitehead dirá que a história da filosofia não passa de uma sucessão de notas de rodapé da obra de Platão. Ou, como afirmará o francês François Châtelet, somos todos discípulos de Platão (COLEÇÃO OS

PENSADORES, HISTÓRIA DA FILOSOFIA, 2004, p. 46).

Mesmo entendendo como excessivos esses comentários, o certo é que Platão constrói uma das maiores obras do pensamento filosófico. 
Possivelmente, por receber em sua formação intensa influência do pensamento socrático, marcando profundamente sua educação e sua obra, alguns historiadores da filosofia identificarão em muitas passagens dos Diálogos de Platão (1995) forte aproximação com seu mestre. Contudo, este fato não diminui em nenhum momento a originalidade ou personalidade encontrada em toda extensão de sua produção filosófica.

Por conseguinte, devido a esta proximidade intelectual do seu mestre, Platão inicialmente inquieta-se com sua própria formação aristocrática, bases que modelaram sua educação e pelas quais está subjugado. Segundo GHIRALDELLI (2009), a partir desse momento Platão passa a problematizar de forma contundente como a elite dirigente, condutora da política em seu tempo. Tornando-se, portanto, critico e opositor da forma injusta de se fazer e de se pensar a política a sua época.

Na sua obra A República (2014), Platão em seus diálogos explicita, entre outras coisas, sua percepção de como seria uma sociedade justa. Sua ideia de justiça é delineada através do sistema metafísico no Diálogo de Timeu, em que ele elabora a teoria, segundo a qual o mundo surge por vontade de um criador, o Demiurgo, atribuindo a cada coisa uma dada finalidade. Assim, Platão entende o universo de forma dualista: o mundo inteligível (kosmos noetós) de onde derivam todas as ideias, modelos, formas, que são sempre as mesmas, imutáveis, e de onde nascem todas as ideias de bem e o mundo sensível (kósmos horatós), onde se encontram as ideias pelas quais percebemos as coisas, como elas surgem e desaparecem aos sentidos, ou seja, mutáveis (CHAUÍ, 2009). 
Já no Dialogo de Fédon, na mesma obra, Platão estabelece sua teoria das almas. Para ele, a alma tem a função mediadora entre o universo sensível e o universo inteligível. Platão distingue três partes da alma: alma racional (razão),formada pela alma superior, destina-se ao conhecimento das ideias e localiza-se na parte superior, tem como atributo principal a sabedoria. A alma irascível, está associada à vontade, dando ao homem o ânimo necessário para enfrentar os problemas e os conflitos, localiza-se no peito e tem como atributo primário a força. Já a alma concupiscente, a mais inferior de todas, se constitui pelos desejos e necessidades básicas. Localiza-se no ventre e tem como atributo a moderação. Por acharemse hierarquizadas as várias estruturas que compõem a alma têm na alma racional a papel de buscar educar as outras duas almas no sentido das ideias de bem, justiça, a felicidade.

A “irascível", por sua natureza, encontra-se predominantemente do lado da razão, mas pode aliar-se também àparte mais baixa da alma, caso seja corrompida por má educação. Existe, portanto, correspondência perfeita entre as virtudes da Cidade e as virtudes do indivíduo. O indivíduo é "temperante" quando as partes inferiores da alma se harmonizam com a parte superior e a ela obedecem; é "forte" ou "corajoso" quando a parte "irascível" da alma sabe manter com firmeza os ditames da razão em meio a todas as adversidades; é"sábio" quando a parte "racional" da alma possui a verdadeira ciência daquilo que é útil a todas as partes (ciência do bem). E a "justiça” será aquela disposição da alma pela qual cada uma de suas partes realiza aquilo 
que deve e do modo como deve realizar (REALE, 2003, p. 160).

Este princípio educativo presente na teoria platônica das almas está baseado na visão de um homem virtuoso. Com isso, Platão constrói algo que vai além de possíveis entraves psicológicos que a teoria da alma possa suscitar e propõe um modelo no qual os valores éticos sejam compreendidos pela educação e pela filosofia universalmente livres de qualquer questionamento, mas guiadas sempre pela razão.

Com isso, Platão pretende explicar a forma como a alma busca superar as paixões e os desejos originários do corpo e como o homem deve adquirir a justa virtude denominada de temperança. Neste sentido, não sujeitar a alma racional às suas camadas inferiores será fundamental para que o indivíduo se torne um ser virtuoso. Sendo que esta virtude consistirá a base do caminho para o autoconhecimento. Deste modo, o surgimento do homem justo, defende Platão, nasce naquele que consegue dominar as paixões da matéria, a cólera, os apetites e desejos da alma pelo aprimoramento do uso da razão.

Consequentemente, segundo Platão, a percepção de virtude no homem passaria necessariamente pelo respeito aos elementos que constituem a natureza primária da realidade humana que atuariam em uma sociedade justa. E, para tal, ele vai advogar uma profunda mudança na cultura e na educação, de modo que se construa a justa paideia. Assim, reafirmando a verdadeira ideia de justiça. Com isso, ele pretende se distanciar definitivamente do modelo mítico e épico de conceber a educação para pensá-la em novas bases, sob a primazia da razão e em busca do logos. 
Para tanto, estas novas bases educacionais estarão diretamente ligadas à capacidade que o homem terá em assimilar os valores morais aos valores do conhecimento. Por conseguinte, sua preocupação maior se volta para uma educação em que o homem priorize a justiça, mesmo reconhecendo que esta forma de educador, necessariamente não assegure sua intenção - já que, o homem pode se desviar deste caminho. Neste sentido, procura, por um lado, desenvolver meios educativos que garantam a formação da alma virtuosa e, por outro, pensa nos processos de degenerescência inerentes às modalidades do estado. Nesse sentido, segundo JAEGER:

Platão tira imediatamente daqui outra consequência: se só existe uma forma de justiça, existem, em contrapartida, muitas formas de degenerescência dela, com o que desperta de novo em nós a recordação da medicina e da saúde. E assim, em face do Estado "natural" da justiça e da alma que a ele corresponde aparece uma pluralidade de formas degeneradas de Estado e de alma. A missão da educação, que até aqui, parecia limitar-se à formação do tipo normal e "natural" da alma sã, é, assim ampliada de chofre para abranger uma esfera nova: a do conhecimento das modalidades anormais do Estado e das formas de degenerescência da cultura do indivíduo que lhes correspondem. A união de ambas as partes, a filosofia da educação, condicionada essencialmente à composição do Estado platônico e só pode compreender-se e justificar-se tomando por modelo a ciência médica (JAEGER, 1995, p. 812). 
Por conseguinte, a tese da paideia postulada por Platão incorpora ideias reparadoras para alma, suficientemente forte no combate a degenerescência do estado. Com isso, Platão pretende, em suas ideias um poder livre de sinais egoístas e ilógicos, um poder apenas e tão somente voltado para a vontade pura, que em essência visa o bem.

Ainda em A República (2014), Platão, sugere o que seria a educação do povo em uma sociedade justa. Uma formação especial e distinta, filosófica para aqueles que terão a missão de governar. Ele expõe sua compreensão do que é o processo pedagógico filosófico através da "alegoria da caverna", método pensado e desenvolvido pelo filósofo ao assumir o governo.

Conta, então, a historieta que havia alguns prisioneiros em uma caverna, presos e acorrentados numa situação de só poder olhar para sua frente, no fundo da caverna. Estes prisioneiros jamais poderiam sair desta caverna. Deste modo, eles nunca conheceriam o mundo real, a parte exterior da caverna. Entre os prisioneiros e o muro há uma fogueira que queima constantemente. O fogo ilumina imagens de bonecos que estão colocados sobre o murro, produzindo efeitos de sombras projetadas na parede do fundo da caverna. Então, tudo o que os prisioneiros veem são os movimentos provocados pelo efeito do fogo sobre os bonecos, resultando nas sombras avistadas por eles.

Em função disto, os prisioneiros passam a acreditar que as sombras existentes fazem parte da realidade, efetivamente são seres reais. Em determinado momento um dos prisioneiros consegue fugir da caverna e ao chegar do lado de fora, ao se deparar com sol (a luz), inicialmente não consegue enxergar 
e por alguns instantes quase o cega. Mas, logo volta a enxergar e a perceber o mundo exterior, à caverna, com seus contornos, formas variadas e cores múltiplas. Ele logo passa a atribuir a esta nova visão de realidade um grau maior do que sua visão anterior, ou seja, das sombras projetadas na caverna. Com isso, o prisioneiro, agora livre das amarras, percebe que as sombras são as verdadeiras ilusões e não são seres reais a se movimentarem, e sim, vultos dos bonecos projetados na parede.

Platão recoloca a questão refletindo na hipótese do prisioneiro liberto em algum momento, se dispôs em voltar à caverna, relatando aos que permaneceram acorrentados sua façanha, que ele, de fato, agora, enxergou a realidade daquilo que pensará ser ilusão, fatalmente eles não acreditariam em seu feito, bem como, o castigaria furiosos por terem sidos acusados de não enxergarem a realidade.

Neste sentido, para GHIRALDELLI (2009):

O que está em jogo são as distinções entre o mundo inteligível, que no limite é banhado pelo Sol, que faz o papel do bem, e o mundo sensível e ilusório, que é o mundo representado, na alegoria, pelas sombras. Todos os homens estão, é claro, no mundo sensível. Andam, comem, dormem - assim vivem no mundo que é continuamente mutável, do fluxo de alternância, que Heráclito viu como sendo o mundo real. Ora, é um mundo existente, porém imperfeito. O mundo imutável, o que se pode chamar de real, não é uma realidade perfeita; no entanto, neste mundo, com o os pés no chão, pode-se captar a que está na realidade não sensível, no mundo real daquilo que não muda: o lugar das formas. Todas as formas estão ali, reais, 
e o ambiente é alimentado e mantido por uma das formas, a forma do bem - que, na alegoria da Caverna, É o Sol (GHIRALDELLI, 2009, p. 79).

Com efeito, se pode inferir, nesta direção, que a ideia de educação platônica está voltada para impulsionar a juventude na direção dos universais, aprendido como real, mas, tendo consciência que o universo sensível, mesmo que exista, é ilusório.

Retomando a discussão da ideia de paideia justa, defendida por Platão em A República, será indispensável a educação caminhar no sentido da virtude humana, numa convergência para o estado justo. Esta formação está diretamente ligada ao desenvolvimento das condições virtuosas e verdadeiras conduzidas pelas ideias de bem. Isso seria possível à medida que as paixões e desejos da alma se tornassem subordinadas as virtudes do bem, como também a partir da emancipação humana do universo sensível.

Em síntese, que fosse possível guiar a visão do pensamento em direção ao mundo inteligível, das ideias imutáveis. Mais ainda, uma educação com ênfase na cultura, próxima dos atributos superiores da alma, formando-a para exercer a supremacia sobre as faculdades inferiores, as coisas mutáveis, temporais e corruptíveis.

Assim, entende Platão que a paideia é à base da formação do homem grego, numa perspectiva do estado governado pela justa razão, suplantando as camadas inferiores da alma humana. Estariam, então, a partir destas inferências, colocados os objetivos e condição para a efetivação da cidade justa, onde o povo buscaria sua formação, sempre 
em conformidade com sua própria condição de classe, se adequando às leis do estado justo.

Estão postas, desta maneira, a função da filosofia defendida por Platão, sendo o filósofo seu condutor. Tendo como premissa, se afastar das coisas do mundo sensível, ou seja, das coisas mutáveis, temporais e corruptíveis, não se deixando levar pelas paixões e desejos. De posse destes atributos o filósofo estaria preparado para governar, mas, especialmente educar os cidadãos para a justiça e para a verdade. Conforme argumenta JAEGER:

[...] para Platão, a tese do reinado dos filósofos nasce da consciência de que é a Filosofia a força construtiva deste novo mundo em gestação, isto é, precisamente aquele espírito que o Estado pretende destruir na pessoa de Sócrates. Só ela, a força que criou o Estado perfeito no mundo do pensamento, é capaz de colocálo em prática, se lhe derem o poder necessário para o fazer (JAEGER, 1995, p. 839).

Ainda segundo o autor, Platão advoga que, por seus atributos, os filósofos devem ser os verdadeiros mestres, ensinado os cidadãos no estado, por serem naturalmente reconhecidos como referências de sabedoria e justiça, podendo ser seguidos e copiados com facilidade. Isso em função das qualidades adquiridas por suas almas, agora, instruídas pela razão.

A percepção da sabedoria que norteia o deslocamento do mestre filósofo do universo sensível em direção ao mundo inteligível das ideias, do bem, por intermédio do uso da razão e da dialética, indica o modelo, o espelho a 
ser seguido pelo cidadão comum na polis. Esta imagem introjetada do mestre filósofo como protótipo e exemplo de conhecimento e virtude implica a condição de uma prática filosófica em oposição aos prazeres mundanos - ascetismo, neutralizando qualquer tendência em contrário advinda do mundo corruptível.

Por conseguinte, os saberes, que serão praticados e estarão a serviço do ensino exercido pelo mestre filósofo, são os valores do conhecimento, do qual lhe é próprio e legitimado pela concepção do modelo educacional de um ideal de estado justo e pela divindade. Assim Jaeger comenta:

Converter-se-á em 'demiurgo' e trocará a única tarefa criadora que nas circunstâncias atuais lhe é dada realizar, a sua própria formação, pela formação de caracteres humanos, tanto no campo da vida privada como no do serviço público. Converter-se-á assim no grande pintor que estruturará a imagem da polis autêntica à luz do modelo divino que traz dentro de si (JAEGER, 1995, p. 861).

Tal poder lhe é outorgado primeiramente pelos saberes que lhe são próprios, bem como pelo estado, e referendado pelos ideais divinos que possui, restando ao povo amá-lo enquanto sábio e seguir seus ensinamentos, apresentando-se a serviço do estado justo, buscando sua formação de cidadão.

Tanto essa teoria pedagógica quanto o ideal político em que se fundamenta-se enraizaram profundamente no pensamento e na cultura ocidental. Por elas, a educação tornou-se sinônimo de cultura do espírito, sendo pensada 
como um meio de livrar o homem de sua natureza corpórea e mundana, na qual estaria aprisionado. Assim, o paradoxo entre a educação como um livre desenvolvimento das faculdades naturais e a educação como um processo de restrição dessa mesma liberdade parece se desfazer na obra de Platão na medida em que postula uma restrição imediata da liberdade, tendo em vista o seu verdadeiro conceito; o sumo bem a serem realizados plenamente apenas na cidade justa.

Aristóteles (384 a.C.-322 a.C.) nasceu em Estagira, na Calcídia, era professor e criou sua própria escola, o Liceu. Não escreve uma teoria específica sobre educação, mas, ao se estudar sua obra, principalmente Ética a Nicômacos (2009) e A Política (2006), se encontra ambiente suficientemente consistente para que se possam identificar elementos teóricos voltados para a educação. Nesta perspectiva, de uma forma geral, se pode pensar que as teses defendidas nestes dois textos permitem a este estudo falar em uma pedagogia aristotélica direcionada para a virtude e para a política, enquanto processo educativo do cidadão inserido na polis. Desta forma, estas duas obras oferecem os elementos pedagógicos de uma educação para o bem viver.

Contudo, o modelo pedagógico aristotélico, neste estudo, estará muito próximo da pedagogia platônica no sentido da paideia, descrito a partir do século V a.C. Esta definição propõe aos gregos um modelo de educação fortemente vinculado à formação integral do cidadão, tornando-o um homem de bem e virtuoso (JEAGER, 1995).

Mesmo reconhecendo a discussão semântica da palavra Paidéia, esta será tratada neste trabalho como um processo 
educativo para cultivo das virtudes superiores do homem em si mesmo, e do homem na polis pela ação e atitude do bem. Por este conceito hermenêutico, este estudo busca fazer uma interface com a expectativa grega do ideal educativo.

Neste sentido, a educação proposta por Aristóteles pretende construir um conjunto de situações concretas que leve o homem a buscar aquilo que lhe é próprio por natureza, em potência, ou seja, a capacidade de tornar-se naquilo que esta subjacente: ser racional, ser social, um ser que pertence ao estado.

Por conseguinte, a teoria das quatro causas que tenta dar conta da questão do movimento, coloca e estabelece as condições para que este estudo possa especular a compreensão das potencialidades naturais aristotélicas no campo pedagógico; causa material: aquilo que constitui as coisas, causa formal: natureza partícula que determina a matéria, causa eficiente: ação que produz o movimento e atua na transformação, dando forma a matéria e, por último, a causa final: trata-se da intenção, objetivo ou finalidade que uma determinada coisa se constitui.

Aristóteles compreende que a causa finalista está contida também e expressa no processo da vida animal e vegetal em sua própria essência. Neste sentido, se busca inferir a idéia de uma maior importância atribuída por ele a "causa final". Esta ilação parece ficar claro através do pensamento de S. Tomás de Aquino na obra Suma Teológica. (2003) vol. III, pg. 150: "E como todo agente age em vista de um fim". Mas também, através do exemplo demonstrado pelo próprio Aristóteles em que descreve um escultor que esculpi a estatua do saldado ateniense com a finalidade de exaltar o heroísmo grego. 
É, portanto, através do deslocamento dos mesmos efeitos especulativos das causas finais aristotélicas que este estudo pretendem reconhecer o conhecimento enquanto finalidade da educação, formando o indivíduo para o bem viver na sociedade. E, para tal, necessita de uma ação pedagógica que contemple a máxima de que o cidadão está contido no estado.

Como não há senão um fim comum a todo o Estado, só deve haver uma mesma educação para todos os súditos. Ela deve ser feita não em particular, como hoje, quando cada um cuida de seus filhos, que educa segundo a sua fantasia e conforme lhe agrada; ela deve ser feita em público. Tudo o que é comum deve ter exercícios comuns. É preciso, ademais, que todo cidadão se convença de que ninguém é de si mesmo, mas todos pertencem ao Estado, de que cada um é parte e que, portanto, o governo de cada parte deve naturalmente ter como modelo o governo do todo (ARISTÓTELES, 2006, p. 78).

Neste contexto, encontramos duas afirmações imprescindíveis para uma boa ação pedagógica. Primeira: somos partes de um todo. A segunda; o governo do todo deve dirigir o governo das partes. Unindo as duas afirmações podemos inferir que a educação deve formar o indivíduo para se tornar cidadão e este deve harmonizarse com o todo. Como cada indivíduo é parte viva do todo, deve receber uma educação que seja pública, isto é, a mesma para todos, pois somente pela educação pública o indivíduo tornar-se-á um bom cidadão. 
Em conclusão, fica demonstrado neste estudo que a filosofia ocidental na forma como ela se consolida em nossa formação foi inaugurada com a perspectiva de encontrar a realidade do mundo nela mesma e não mais no divino, no mito. Procura questionar, desta forma, a validade do conhecimento mítico. Neste sentido, o texto traz as teses dos três grandes filósofos clássicos como primeiro grande exercício do conhecimento, além do compromisso com a verdade. Verdade esta, percebida tal qual ela se apresenta ao homem que aplica a razão na sua descoberta. Assim, para os três filósofos gregos as explicações dadas aos fenômenos da nossa experiência deveriam ser encontradas na própria natureza das coisas.

Como resultado deste processo especulativo destaca-se a figura de Sócrates - Considerado o grande educador da Grécia antiga, ele busca através do seu método de ensino, estimular a procura da verdade, ou seja, despertar no homem o conhecimento de contido em si próprio. Acredita em um saber interior verdadeiro.

A pedagogia socrática consistia em convidar seus discípulos para o desapego dos conhecimentos postos. Em seus ensinamentos públicos nas praças, conduzia os jovens a refutarem os conteúdos prontos de maneira irônica. Com isso, Sócrates cria seu método pedagógico a maiêutica, pelo qual ele interrogava seus discípulos, ajudando-os a parir, trazer à luz as ideias e os esclarecimentos apresentados para os fenômenos da realidade da natureza das coisas.

Em síntese, a tarefa essencial da educação socrática é fazer com que o homem emerja do mundo das aparências, enxergando a luz do "verdadeiro ser". 
A filosofia platônica irá procurar em seu modelo educativo (paideia) ser capaz, de contestar aquilo que fora produzido nas teses defendidas pelos sofistas. Suas ideias pretendiam reestruturar as coisas que denominava como prejudicial aos cidadãos gregos, posto pelos sofistas, colocando-os no caminho reto. Para tal, a filosofia platônica pretende educar o homem sob a primazia da razão, e essa, deveria se sobrepor as esferas inferiores da alma humanas, a temperança, fazendo-a abandonar as paixões e os desejos.

Estes seriam, portanto, os predicados essencias, prescritos por Platão para a construção do estado justo no qual o povo deveria ser educado em conformidade com aquilo que lhe é próprio por natureza evocando do estado justo, suas leis justas. Estão, portando, a partir destas inferências dadas as bases contidas na educação idealizada por Platão que visava conduzir o homem através de suas pré-disposições racionais, orientado pelas leis de um estado justo, bem edificadas num estado ideal.

É possível concluir que Aristóteles o último dos filósofos da tríade clássica, não era idealista como seu mestre Platão. Defendia práticas mais racionais. Pensava que as ideias estavam nas coisas, ou seja, na própria essência. Sua proposta educacional estaria assentada em três principais vertentes que por sua vez seriam fruto do desenvolvimento virtuoso do homem: sua potencialidade inata, seu hábito e a sua educação. Ele acreditava que o homem poderia vir a ser uma criatura de valores mais elevados pela prática da ação nobre. Onde se educava na própria prática, no próprio habito da ação virtuosa realizada. Assim, segundo Aristóteles, aprende-se fazendo, e se educa ao tornar-se mais justos, isto é, agindo justamente. 
Em suma, este estudo procurou delinear alguns aspectos filosóficos imbricados com a temática da educação a partir de um olhar voltado para o pensamento dos três maiores representes do período clássico: Sócrates, Platão e Aristóteles.

\section{NOTA}

${ }^{1}$ Professor do IF Baiano (Instituto Federal de Educação, Ciências e Tecnologia Baiano), Campus Governador Mangabeira/Bahia. Doutor em Ciências da Educação pela Universidade Americana/Assunção - Paraguai. Email: sudelmar@terra.com.br.

\section{REFERÊNCIAS}

ABBAGnANO, N. Dicionário de filosofia. 1. ed. São Paulo: Martins Fontes, 2007.

ABRÂO, B. S. (Org.). História da filosofia. Coleção os Pensadores. 1. ed. São Paulo: Nova Cultural vol. I, 2004.

AQUINO, T. Suma Teologia. Vol. III, São Paulo. Ed. Loyola, 2003.

ARANHA, M. L. A.; MARTINS, M. H. P. Filosofando. Introdução à Filosofia. São Paulo. Moderna, 2003. 
ARANHA, M. L. A.; MARTINS, M. H. P. História da educação e pedagogia: geral e Brasil. 3. ed. São Paulo: Moderna, 2014.

ARISTÓTELES. A política. São Paulo: Martins Fontes, 2006.

ARISTÓTELES. Etica a nicômaco. São Paulo. Atlas, 2009.

BACHELARD, G. O racionalismo aplicado. Tradução Nathanael Caixeiro. Rio de Janeiro: Jorge Zahar, 1977.

CANTOSPERBER, Monique (Org.). Dicionário de ética e filosofia moral. São Leopoldo - RS: Editora Unisinos, 2003.

CANTOSPERBER, Monique (Org.). Dicionário de ética e filosofia moral. São

CHAUI, M. Convite à Filosofia. São Paulo. Ática, 2010.

COTRIM, G.; FERNANDES, M. Filosofar. 1. ed. São Paulo: Saraiva, vol. único, 2010.

DANILO, M. Iniciação à história da filosofia,dos pré-socráticos a Wittgenstein. 8. ed. Rio de Janeiro: Jorge Zahar, 2004.

GHIRALDELLI, P.J. Filosofia e história da educação brasileira. 2.ed. Barueri, São Paulo, Monole, 2009.

HADOT, P. O que é a filosofia antiga? São Paulo: Lisboa, 1999.

JAEGER, W. W. Paideia: a formação do homem grego. Tradução Parreira, A. M. São Paulo: Martins Fontes, 1995. 
MANACORDA, A. M. História da educação: da antiguidade aos nossos dias. São Paulo: Cortez, Autores Associados, 1989.

MARROU, H. I. História da educação na antiguidade. São Paulo: Editora Herder, 1966.

MINAYO, M. C. S. Pesquisa social: teoria, método e criatividade. Petrópolis/RJ: Vozes, 2001.

MONDOLFO, R. O pensamento antigo. 3. ed. V. 1. São Paulo: Mestre Jou, 1971.

PADOVANI, H.; CASTAGNOLA, L. Historia da filosofia. 10. ed. São Paulo: Melhoramentos, 1974.

PILETTI, N.; PILETTI, C. História da educação. 7. ed. São Paulo: Ática, 2003.

PLATÃO. A república. Rio de Janeiro, Zahar. 2014.

PLATÃO. Diálogos. São Paulo: Cultrix, 1995.

PLATÃO. O banquete. Tradução, notas e comentários de Donaldo Schüler. Porto Alegre: L\&PM, 2013.

REALE, G. História da filosofia antiga.Das origens a Sócrates. São Paulo: Loyola, vol. 1., 1993.

REALE, G. História da filosofia: filosofia pagã antiga, v. 1. São Paulo: Paulus, 2003. 
ASPECTOS FILOSÓFICOS DA EDUCAÇÃO NO PERÍODO CLÁSSICO GREGO

REALE, G. Platão. 2. ed. São Paulo: Loyola, 2007.

SANTOS, B.S. Um discurso sobre as ciências. 10. ed. Porto: Afrontamento, 1998. 